\title{
Maternal Attitudes, Emotional Intelligence and Home Environment and Their Relations with Emotional Intelligence of Sixth Years Old Children
}

\author{
Ilkay Ulutas and Esra Omeroglu \\ Department of Early Childhood \\ Development and Education \\ Gazi University, Ankara \\ Turkey
}

\section{Introduction}

Mayer and Salovey have defined the emotional intelligence "perceiving emotions, using emotions in order to support ideas, understanding emotions and emotional information, adjusting emotions for emotional and mental development" (Mayer \& Salovey 1997). Recently two conceptions of emotional intelligence (trait emotional intelligence and ability EI) have been indicated. Trait EI (or trait emotional self-efficacy) concerns emotion related dispositions and self-perceptions measured via self-report, whereas ability EI (or cognitiveemotional ability) concerns emotion-related cognitive abilities measured via performancebased tests (Petrides et all, 2007).

Emotional intelligence covers abilities like recognising, understanding and regulating emotions which are important for children to establish positive relationships with people (Mayer, Caruso, \& Salovey, 2002, Goleman, 2001). It has come to light that children, who can understand emotions correctly avoid aggressive behaviours, establish more positive relations with their peers and other persons around them and they are accordant in their school and social life (Hughes, Dunn, \& White, 1998, Fabes, et al. 2001).

Emotional intelligence also has a great importance in terms of ensuring social and universal unity. Today in many countries around the world it draw attention that social relationships have been declining and individualism has been arising in parallel with the rapid development of technology and increase in competition trend. Besides the necessity of emotional understanding and control has arisen in order to each individual accepts and works in cooperation with an individual from another culture. In recent years programs that increase emotional and social skills has been preparing and implementing at workplace and schools in many developed countries that acknowledge the importance of togetherness and cooperation Webster-Stratton, \& Hammond, 2010, Elias, et al. 1997, Alegre, 2011). When we look at the results of these programs the decrease in violent behaviour among new generation revealed the importance of emotional intelligence. 
Recent studies show that children interact with emotions before they born. During infancy child tries to recognize the emotions. As Piaget stated between the ages of two and four they display egocentric thinking. In these ages they can interact with adults and their peers freely but they are more focused on their selves and can't comprehend other's standpoints. However in following years with the increase of their need for association with friends egocentrism should decrease and emotional sharing and emotional control should increase (Berk, 2002). In this regard parents have very important responsibilities for children to turn towards to sharing from egocentric thinking.

Family is the first environment where child feels, observes and learns the emotional relationships (Warhol, 1998). Parenthood contains the skills like struggling against the various dangers that children may face and guiding them in a good way (Melmed, 1998). Children try to understand the emotions through the attachment and modelling with parents (Denham et al., 2000; Laible \& Thompson, 1998; Ontai \& Thompson, 2002; Raikes \& Thomspon, 2006; Suess, Grossmann \& Sroufe, 1992). How much child's attachments with his parents is strong his success increases in relationships with the people and he can establish social relationships without anxiety of acceptance, criticism and loneliness (Kerns, Klepac, \& Cole, 1996).

The risk factors that lead unwanted behaviours of children who cannot attach securely like fighting, complaining appears in early childhood (Denham, 2007). Therefore it is important to examine the factors affecting the children and parents relationship.

\subsection{Factors affecting children's emotional intelligence}

Several factors affect the development of emotional intelligence in children. Child's character, neurophysiology and cognitive enhancement are the important factors (Eisenberg \& Morris, 2002; Goldsmith \& Davidson, 2004). However it has been seen that emotional intelligence may strengthen or dull with the effect of both these factors and social relationships like family and circle of friends. Family environment is especially the most important one among these (Cole, Martin, \& Denis, 2004; Parke, 1994; Walden \& Smith, 1997).

In Figure 1 family's effect on child's emotional intelligence has been shown.

According to Morris et al. (2007) family environment affects children's emotional intelligence in three aspects. Firstly children learn emotions by observing the people around them. Secondly their experiences and behaviours related to parent's emotions ensure children to become appropriate to society's expectations. Thirdly factors reflecting the emotional status of family such as the quality of emotional attachment between the child and the parents, attitude of parents, emotional and social openness, and marital relationship have impacts on emotional intelligence.

\subsection{Emotional intelligence and parenting styles}

Baumrind denotes ideal parents as "parents who manage child's activities in a rational way, promote verbal communication within the family, talk about their attitudes regarding child raising with the child, support child to overcome the obstacles that the child faces when he cannot adjusted" (Baumrind, 2005). As stated attitude of parents bring along with positive 
results as self control of child, self adjustment, adaptation and friendly relations (Jewell et. al., 2008).

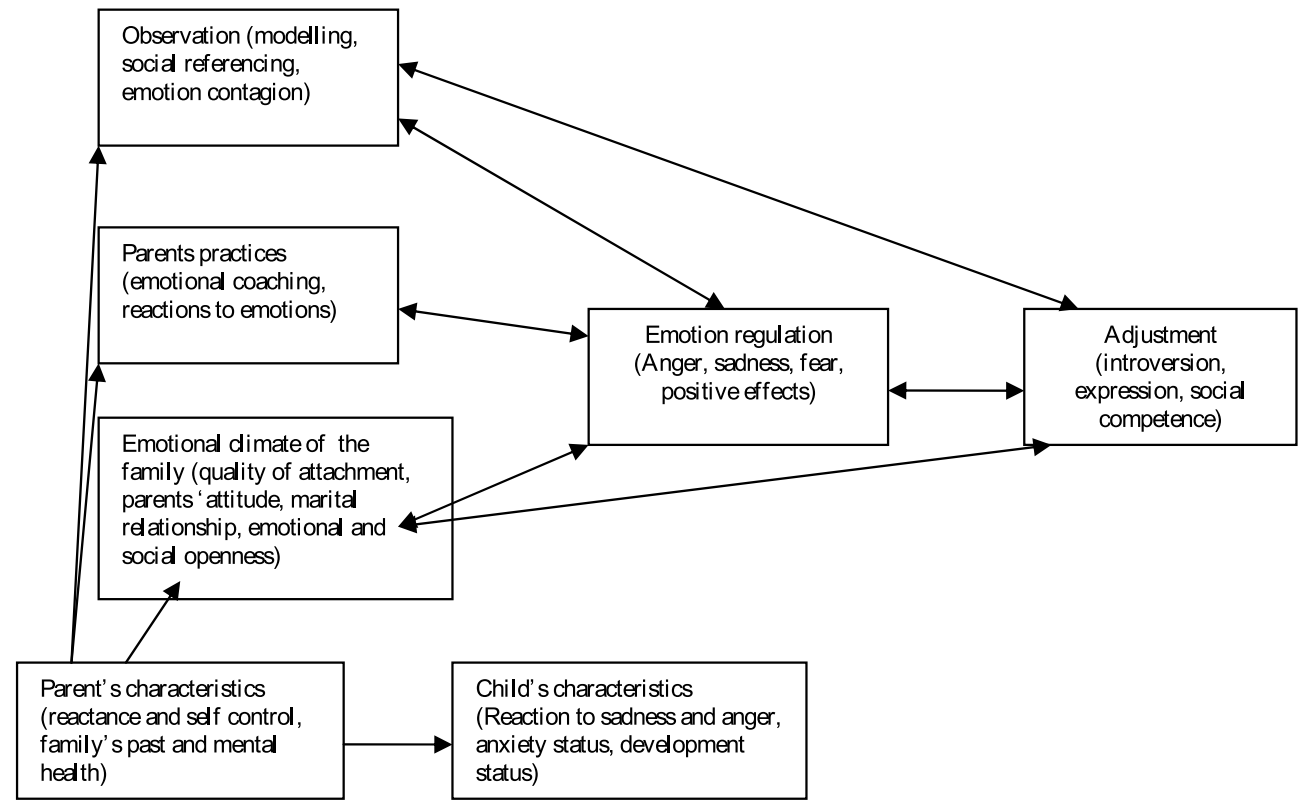

(Morris et al., 2007, p.362)

Fig. 1. Familial factors affecting emotional intelligence

Alegre (2011) reported four main dimensions of parenting are identified that are relevant to the study of emotional intelligence: parental responsiveness, parental positive demandingness, parental negative demandingness, and parental emotion-related coaching. Parental responsiveness, parental emotion-related coaching, and parental positive demandingness are related to children's higher emotional intelligence, while parental negative demandingness is related to children's lower emotional intelligence.

Thompson (1998) indicates that children, who have positive relations with parents and argue the emotions of others, have a better understanding of emotions when compared with others. Children learn emotions from their parents' speeches and enhance their emotional intelligence through the bond they attached with their parents (Raikes \& Thompson 2006).

In a research by Chen et al. (2005) on attitudes of parents and children's social adaptation, it has appeared that supportive parenting attitude is influential on development of children's social adaptation.

Child raising attitudes of parents also affects the emotional environment of the family (Lopez, Bonenberger and Schneider; 2001), it was found that excessively authoritarian attitude of parents is associated with the low empathy level of child while inductive attitude is associated with high empathy level. It appears that authoritarian parents limit their child further (Marr \& Ezeife, 2008). 
Parenting styles associated with poor child emotion regulation, dismissive and disapproving responses to displays of emotions (Gottman et al., 1997; Ramsden \& Hubbard, 2002). Ramsden and Hubbard (2002) found dismissive parenting was associated with poorer emotion regulation and increased aggressive behaviour in preschoolers. Denham and colleagues (2000) found a similar relationship, and concluded that dismissive parenting may be worse for children with more difficult temperaments. Also in several studies show that parents are influential on child's emotional reaction, motivation status, behaviours and emotional control (Eisenberg, Cumberland, \& Spinrad, 1998; Gottman, Katz, \& Hooven, 1997). Accordingly parents with warm and positive attitude will raise children who experience less anger and temper or who have fewer problems like aggressiveness stems from these emotions (Eisenberg et al., 2005).

\subsection{Emotional intelligence and home environment}

While parents' interaction with child and their form of attachment affect the emotional intelligence of child, home environment can be seen as a natural environment for the constitution of emotions and emotional attachments (Raikes, \& Thompson, 2006). Parents' style of communication with the child, child's acceptance at home, the way they support the development and learning of child, signals they send to child, modelling, and physical environment are presumed as the indicator of sufficiency of home environment (Caldwel \& Bradley, 1984).

Home environment is important in terms of ensuring the child to overcome the emotional barriers (Parke, et al., 1992; Thompson, 1994). It has appeared that negative impacts in home environment; especially mother's angry and furious communication style lowers preschool children's understanding of emotions. Nixon and Watson (2001) observed that children with positive home environment animate spousal relations positively in puppet plays while children who are subject to negative impacts animate it negatively. According to the study by Chen et al., (2005) parents with supportive attitude arrange home environment in such a way that is enhances emotional sufficiency of children. These parents organize home environment based on the thoughts and suggestions of children, choose and place the furniture and materials the way that this provide emotional comfort in order that children see themselves as a member of the family.

\subsection{Aim of the present study}

As stated by Eisenberg et al., (2005) mother's parenting attitudes and interactions with children have more powerful impact on their emotional and social development in the early years. It is also possible that the effects of positive parenting are especially strong in this period when children are more vulnerable and parents are highly salient emotional models compared with other models in their nearby. Therefore this study aimed to determine the relationship between maternal factors such as maternal attitudes, home environment and emotional intelligence and children's emotional intelligence. Mother negative parenting style was hypothesized to be negatively associated with child's emotional intelligence. Home environment was expected to be positively associated with child's emotional intelligence. Maternal emotional intelligence was hypothesized to be positively associated with child's emotional intelligence. 


\section{Method}

\subsection{Participants}

144 sixth years old preschool children (78 boys and 66 girls) at two separate preschool sites, and their mothers, and teachers participated in the study. Sixth years old children were chosen because the early years were marked by the emergence of self regulatory capacities and an increase and diversification of emotional regulation abilities (Maughan \& Cicchetti 2002; Cicchetti \& Schneider-Rosen 1986). Children were recruited from the preparation classes of the primary schools at the centre of Ankara. All of them were Turkish and living in a household with both biological parents. The majority of the children had middle socioeconomic status.

The mothers were aged from $20-40$ with a mean of 29 years $(S D=3.42)$. The education level of the mothers ranged from less than 5 years of schooling to university graduates. 47.1 percent of mothers had less than high school education, 36.9 percent had a high school diploma, 16.0 percent had graduated from university. Most of them were from workingclass families with a mean income of $\$ 1000$ to $\$ 2000$. The majority of the mothers had two children $(62.7 \%, \mathrm{~N}=153)$, the next largest group had one child $(23.8 \%, \mathrm{~N}=58)$. More than half of them were not working at the time of the study $(61.9 \%, \mathrm{~N}=151)$.

Classroom data were collected from ten teachers at two separate primary schools. Both schools were within public school districts, serving normal population. The teachers had bachelor's degree in early childhood teaching.

\subsection{Measures}

Demographic information obtained included sex, age, current living arrangements, participants' birth order and parents' age, educational status, job etc..

\subsubsection{Children' emotional intelligence: The Sullivan Emotional Intelligence Scale for children, the Sullivan Brief Empathy Scale for children and the Sullivan Teacher Rating Scale of Emotional Intelligence for children were utilized}

The Sullivan Emotional Intelligence Scale (Sullivan, 1999) consists of three main parts such as; Recognising emotions (with Faces and Stories subtest), Understanding emotions and Managing emotions. There are 19 faces in the faces subtest of Recognising section, 5 short stories in stories subtest of Recognising section, such as thunder, death of animal, 10 vignettes in the Understanding section and 7 interactive stories in the Managing section and 7 items in the managing section. The researcher read the each items to child and asks the questions following the item. The child is required to respond with "yes" or "no" or "I don't know".

The Sullivan Brief Empathy Scale for Children was designed to provide information about children's emphatic reactions. It contains ten items. The researcher read the each items to child, the child is required to respond with "yes" or "no" or "I don't know".

The Sullivan Teacher Rating Scale of Emotional Intelligence for Children is a scale of 11 items, from the lowest level perception of emotions to the highest level which is managing emotions. The teacher completes it for each child depending on classroom observations. 
Items were first translated into Turkish and then back translated into English. Items with problematic back translations were thoroughly discussed and appropriately amended. Turkish adaptation of the scales proved adequate validity $(\alpha=0.68-0.90)$ and reliability $(.97-$ .99). Scales have two dimensions one from the researcher and other from the teacher to ensure a fairer assessment of each child's emotional intelligence (Ulutaş \& Omeroglu, 2007).

\subsubsection{Maternal emotional intelligence: Mothers' emotional intelligence was measured with the emotional intelligence self-evaluation test}

This test was designed by Hall and adapted and translated into Turkish by Ergin (2000) and consists of 30 items. The scores received from the scale range between 30 and 180 and higher scores indicate higher emotional intelligence. When observed in terms of total score, a correlation coefficient at the level of 0.84 was found between the first and last application.

\subsubsection{Maternal attitudes: Parental Attitudes Research Inventory (PARI)}

The Parental Attitudes Research Inventory, developed by Schaefer and Bell, was used in this research to determine the attitudes of mothers towards their children. The test was adapted and translated into Turkish by LeCompte et al. (1978). There are 60 items and 5 subscales in the test. The subscales include overprotective mothering, democratic attitudes and recognition of equality, rejecting the role of housewife, marital conflicts, and strict discipline. A total score cannot be obtained from the scale; however, factor scores can be evaluated.

\subsubsection{Home environment: Home observation for measurement of the environment (Home) inventory}

This inventory was developed by Caldwell and Bradley (1984) in order to examine the facilities provided for children at home by the family and to observe the children's interaction with their mother. A validity and reliability study of the inventory on Turkish children was conducted by the researchers. The reliability coefficient emerged as .69. The inventory consists of eight subsections and a total of 55 items on the following aspects; "supporting learning", "supporting speaking", "physical environment", intimacy and acceptance", "academic stimulation", "modelling", "variety in experience" and "acceptance". The score received from the inventory are evaluated and higher scores point to a positive outcome in terms of home environment observation.

\subsection{Procedure}

Contact with most of the participants was made via a preschool teacher. The first 144 mothers and their children who expressed interest in participating were contacted to collect the data. A letter describing the study along with consent forms was sent to the parents of all the children in this study. Once consent from the parents was obtained, the surveys of demographic information, Emotional Intelligence Self-Evaluation Test and Parental Attitudes Research Inventory were sent home to mothers. The mothers were instructed to complete the measures independently, with these instructions provided in writing as well as verbally.

At the same time the researchers paid visits to mothers at home to fill the Home Observation for Measurement of The Environment (Home) Inventory. Home visits took approximately 40 minutes for per child. During this time mother's interaction with children and home 
environment of the child were observed and Home Observation Inventory completed by the researchers.

Children were assessed by the researchers using The Sullivan Emotional Intelligence and The Sullivan Brief Empathy Scale at the school in the interview room. It took 30-40 minutes per child. Additionally teachers completed The Sullivan Teacher Rating Scale of Emotional Intelligence for Children.

\subsection{Data analysis}

Firstly, gender differences in emotional intelligence were assessed performing Independent Sample T test. Secondly, relationship between the independent variables (mother emotional intelligence and parental styles, and home environment) and dependent variable (children emotional intelligence) was ascertained using the corresponding scores obtained from the variables and tested the same through bivariate correlation coefficient statistics. Finally simultaneous and multiple regression analyses were found out the predictors of children' emotional intelligence.

\section{Results}

\subsection{Preliminary analyses}

Because some researchers have found gender differences in emotional responding and managing (Goodvin, Carlo, Torquati, 2006) and to examine possible gender differences in the emotional intelligence Independent Sample t test was performed.

\begin{tabular}{llllll}
\hline & Sex & $\mathrm{N}$ & Mean & $\begin{array}{c}\text { Std. } \\
\text { Deviation }\end{array}$ & \\
\hline Recognising emotions & & & & & \\
Faces & Girl & 66 & 14.23 & 2.12 & \\
& Boy & 78 & 14.71 & 2.01 & $\mathrm{t}_{(142)}=-1.39$ \\
Stories & Girl & 66 & 3.83 & .83 & \\
& Boy & 78 & 3.49 & 1.07 & $\mathrm{t}_{(142)}=2.14^{*}$ \\
Understanding & Girl & 66 & 7.50 & 1.69 & \\
Managing emotions & Boy & 78 & 7.31 & 1.64 & $\mathrm{t}_{(142)}=.69$ \\
& Girl & 66 & 4.61 & 1.51 & \\
Total EI & Boy & 78 & 4.80 & 1.59 & $\mathrm{t}_{(142)}=-.73$ \\
& Girl & 66 & 30.17 & 3.91 & \\
Empathy & Boy & 78 & 30.30 & 4.41 & $\mathrm{t}_{(142)}=-.18$ \\
\multirow{2}{*}{ Teacher ratings } & Girl & 66 & 9.38 & 1.05 & \\
& Boy & 78 & 9.28 & 1.15 & $\mathrm{t}_{(142)}=.52$ \\
\hline
\end{tabular}

${ }^{*} \mathrm{p}<.05$

Table 1. Children's gender differences and emotional intelligence 
An independent samples t-test revealed significant gender differences in "defining emotions" subtest of emotional intelligence $(\mathrm{t}=2,297 \mathrm{p}<0.05)$ with girls scoring higher than boys $(\mathrm{M}$ (girls) $=3,89, \mathrm{SD}=0.84 ; \mathrm{M}$ (boys $)=3.51, \mathrm{SD}=1.10)$. However, there were no significant differences in Understanding Emotions $\left(\mathrm{t}_{(142)}=, 693\right)$, Managing Emotions $\left(\mathrm{t}_{(142)}=\right.$ ,727), Total EI $\left(\mathrm{t}_{(142)}=-, 183\right)$, Empathy $\left(\mathrm{t}_{(142)}=, 524\right)$ and Teacher ratings $\left(\mathrm{t}_{(142)}=, 1,434\right)$.

\subsection{Correlations}

Correlations among children emotional intelligence and maternal attitudes, home environment and maternal emotional intelligence are shown in table 2. Recognising emotions was negatively associated with overprotective attitudes of mothers (faces: $r=-17$, $\mathrm{p}<.05$ ) and home environment (stories: $\mathrm{r}=-20, \mathrm{p}<.05$ ) on the other hand positively correlated with maternal emotional intelligence $(\mathrm{r}=24, \mathrm{p}<.01)$. Understanding emotions was negatively associated with overprotective attitudes $(\mathrm{r}=-16, \mathrm{p}<.05)$ but positively associated with democratic attitudes $(\mathrm{r}=20, \mathrm{p}<.05)$. Overall there were negative relationship between children' total emotional intelligence and maternal overprotective behaviour $(\mathrm{r}=-20, \mathrm{p}<.05)$ and positive and strong relationship with maternal emotional intelligence $(r=20, p<.05)$.

\begin{tabular}{|c|c|c|c|c|c|c|c|c|c|c|c|c|c|c|}
\hline & 1.a & $1 b$ & 2 & 3 & 4 & 5 & 6 & 7 & 8 & 9 & 10 & 11 & 12 & 13 \\
\hline $\begin{array}{l}\text { 1. Recognising } \\
\text { emotions } \\
\text { 1a.Faces }\end{array}$ & & $.27^{* *}$ & $.29^{* *}$ & .11 & .11 & -.02 & $.71^{* *}$ & -.04 & $-.17^{*}$ & .03 & .09 & .093 & .06 & $.24^{* *}$ \\
\hline 1b. Stories & & & $.17^{*}$ & .14 & .05 & .10 & $.49^{* *}$ & $-.20^{*}$ & -.09 & .05 & .130 & 15 & .06 & -.05 \\
\hline 2.Understanding & & & & $.44^{* *}$ & $.32^{* *}$ & .06 & $.74^{* *}$ & .04 & $-.17^{*}$ & $.20^{*}$ & -.062 & -.05 & .04 & $.25^{* *}$ \\
\hline 3.Managing & & & & & $.25^{* *}$ & .10 & $.63^{\text {** }}$ & -.07 & -.08 & .01 & .013 & .01 & .06 & .04 \\
\hline 4.Empathy & & & & & & .05 & $.28^{* *}$ & .12 & .02 & .05 & -.086 & -.11 & .02 & .02 \\
\hline 5.Teacher ratings & & & & & & & .08 & .05 & .09 & .09 & $.200^{*}$ & .09 & -.01 & .01 \\
\hline 6.Total EI & & & & & & & & -.07 & $-.20^{*}$ & .11 & .056 & .07 & .08 & $.22^{* *}$ \\
\hline 7.Home environment & & & & & & & & & -.15 & $.24^{* *}$ & -.136 & -.10 & -.15 & $.21^{*}$ \\
\hline 8.Overprotective & & & & & & & & & & -.05 & .161 & .16 & -.07 & $-.27^{* *}$ \\
\hline 9.Democratic & & & & & & & & & & & -.029 & .09 & -.08 & $.39^{* *}$ \\
\hline $\begin{array}{l}\text { 10.Rejecting } \\
\text { Housewife role }\end{array}$ & & & & & & & & & & & & $.71^{* *}$ & -.15 & .00 \\
\hline 11.Marital conflicts & & & & & & & & & & & & & $-.17^{*}$ & .06 \\
\hline 12.Strict discipline & & & & & & & & & & & & & & -.09 \\
\hline 13. Maternal EI & & & & & & & & & & & & & & \\
\hline
\end{tabular}

${ }^{*} \mathrm{P}<.05$ **P<.01

Table 2. Correlations between children emotional intelligence and maternal characteristics

Maternal attitudes accounted for $7 \%$ of the variance in emotional intelligence $\left(\mathrm{F}_{(5,138)}=2.01\right.$ $\mathrm{p}<.05)$. As seen table 3 maternal attitudes results were significant only for the overprotective mothering $(\beta=-.09, \mathrm{p}<.05)$ indicating that overprotective attitudes had negative effect on children's emotional intelligence. Democratic mothering scores were not significant predictors in this analysis. Therefore, it appears that overprotecting attitudes in mothers would be a negative effect on emotional intelligence of children. 


\begin{tabular}{llll}
\hline Independent variables & $B$ & SEB & $\beta$ \\
\hline Maternal attitudes; & & & \\
Overprotective mothering & -.10 & .04 & $-.21^{*}$ \\
Democratic & .11 & .09 & .11 \\
Rejecting the role of housewife & .03 & .06 & .07 \\
Marital conflicts & .04 & .09 & .06 \\
Strict discipline & .06 & .06 & .10 \\
$\mathrm{R}^{2}=.07, \mathrm{~F}_{(5,138)}=2.01^{*}$ & & & \\
Maternal Emotional Intelligence & .02 & .01 & $.22^{*}$ \\
$\mathrm{R}^{2}=.05, \mathrm{~F}_{(1,42)}=7.45^{*}$ & & & \\
Home environment & -.06 & .07 & -.07 \\
$\mathrm{R}^{2}=.01, \mathrm{~F}_{(1,42)}=.75$ & & & \\
\hline
\end{tabular}

${ }^{*} \mathrm{p}<.05$

Table 3. Summary of regression analysis predicting children's emotional intelligence from maternal and home characteristics

Beside this negative predictor, maternal emotional intelligence was found a positive predictor of children's emotional intelligence $\left(\mathrm{R}^{2}=.05, \mathrm{~F}_{(1,42)}=7.45, \beta=.02 \mathrm{p}<.05\right)$. High maternal emotional intelligence predicted high emotional intelligence in children.

Final result from Table 3, revealed that home environment failed to predict the emotional intelligence in children $\left(\mathrm{R}^{2}=.01, \mathrm{~F}_{(1,42)}=.75, \beta=-.06 \mathrm{p}>.05\right)$. In sum, in the light of the analyses it can be seen that maternal protecting and emotional intelligence estimated the children's emotional intelligence stronger than home environment.

\section{Discussion}

This study aimed to evaluate and compare the relationship among children's emotional intelligence and maternal parenting style, emotional intelligence and home environment. The study findings suggest that gender differences partially had effect children's emotional intelligence. Consistent with results of many other studies (Bruno, England, \& Chambliss 2002; Bosacki \& Moore 2004) girls were recognising emotions more than boys.

Compared with the many prior research (Parke, et al., 1992; Thompson, 1994, Nixon and Watson 2001, Chen et al., 2005, McLaughlin, et al. 2007, Scheroeder \& Kelley 2009) the home environment was not found as a significant predictor of children's emotional intelligence in the study. Consistent with this result Schimitz (2006) indicated that home environment was not predictive of child global self-esteem.

Negative associations found between emotional intelligence of children's and mothers' attitudes also. The overprotective attitudes revealed negatively with children's emotional intelligence. In Turkish mothers depending on the cultural characteristics and strict family interactions overprotective mothering has been frequently appeared. For instance Ar1 \& 
Secer (2003) also stated when the Turkish mothers were less protective their children had higher social problem solving capability.

Children's emotional intelligence can be supported with the positive or moderate parental behaviours rather than overprotective and harsh discipline parenting style (Alegre, \& Benson, 2010). Moderate parents appreciate emotions of children and try to understand them through empathy. It has observed that children of this parents are usually conscious about their own selves and their environment, have developed social skills and self esteem, in other words they have high emotional intelligence (Shapiro, 2000, Eisenberg, et al., 2003, Alegre, 2011). Moreover overprotective behaviours of mothers restrict child behaviours, discourage child independence and lead the shyness and internalizing problems in childhood (Rubin \& Burgess, 2002, Coplan, Reichel, \& Rowan, 2009).

The results in this study provide perhaps the strongest support for the hypothesis that how maternal emotional intelligence predicts children's emotional intelligence. Results showed that as mother's emotional intelligence increases, children's emotional intelligence also increases. Parent's internal control, warm and positive family atmosphere also affect children positively (Ozabaci, 2006). Parents which are qualified emotionally seem to place emphasis on emotions within the family, develop empathy, display consistent attitudes and try to solve children's negative behaviours through empathy (Bradley et al., 2008).

In sum outcomes emphasize that mother' attitudes and emotional intelligence has a critical impact on emotional intelligence of children. A progress mother's attitude or emotional skills will lead a progress in emotional intelligence in children. If a child is raised to have poor emotional intelligence, that child is more likely to have difficulty, to make choices that are to his/her own detriment, to have problems dealing with stress and to be an unhappy and angry person (Sung, 2011).

Due to the attitudes of parents have direct effect on children's emotional intelligence, it should be accepted that the enhancement of the parents' attitudes would be the first step to support emotional intelligence of children (Alegre, 2011). While parents' attitudes are supported, children's emotional intelligence and home atmosphere are supported as well. Especially in early childhood it will be more effective to support parents' attitude to improve emotional intelligence of children.

Although there were many studies focus on emotional understanding and regulation and parental factors in school age children very little research aimed to focus on the emotional intelligence in the early years. Despite the potential limitations of survey data, the present study has theoretical and methodological significance. Motherhood is especially centre in emotional intelligence in the early years because child lacks many of the emotional understanding and managing considered necessary for emotional intelligence. Our expectation for the future is to improve all parents and children with emotional abilities.

There are several limitations in the study that should be mentioned. We were interested to study with children and their mothers. The results cannot generalise to fathers. We included children emotional intelligence and maternal factors. It will also be important to explore the role of the peer group in emotional intelligence such as the provision of emotional support and the enhancement of self-regard. Future research could also investigate the emotional intelligence of children who come from different home environments. Finally there is still 
need to further understanding with studies based experimental and longitudinal methods in the area.

\section{References}

Alegre, A. \& Benson, M. J. (2010). Parental Behaviours and Adolescent Adjustment: Mediation via Adolescent Trait Emotional Intelligence. Individual Differences Research 8 (2), 83-96

Alegre, A. (2011). Parenting Styles and Children's Emotional Intelligence: What Do We Know?. The Family Journal: Counselling and Therapy for Couples and Families, 19(1) 5662.

Arı, R. \& Secer, Z. S. (2003). The Effects of The Parents' Attitudes on Children's Psychosocial Based Problem Solving Capabilities. Selcuk University Journal of Social Science, 10, 451-464.

Baumrind, D. (2005). Patterns of Parental Authority and Adolescent Autonomy. New Directions for Child and Adoiescent Development, 108, 61-69.

Berk, L. E. (2002). Infants and Children: Prenatal Trough Middle Childhood. U.S.A.; Allyn and Bacon Publishing.

Bosacki, S. L., \& Moore, C. (2004). Preschoolers' Understanding of Simple and Complex Emotions: Links with Gender and Language. Sex Roles, 50, 659-675.

Bradley, R.G.; Binder, E.B.; Epstein,M.P.; Tang, Y.; Nair, H.P.; Liu,W.; Gillespie, C.F.; Berg, T.; Evces, M.; Newport, D.J.; Stowe, Z.N.; Heim, C.M.; Nemeroff, C.B., Schwartz,A.; Cubells, J.F.\& Ressler, K.J. (2008). Influence of Child Abuse on Adult Depression. Archives of General Psychiatry 65, 190-200.

Bruno, K.; England, E. \& Chambliss, C. (2002). Social and Emotional Learning Programs for Elementary School Students. available from http:/ / search ERIC.Org/ericde/ED463097. htm

Caldwell, B. M., \& Bradley, R. H. (1984). Home Observation for Measurement of the Environment. Revised edition. Little Rock: University of Arkansas at Little Rock.

Chen, X.; Chang, L; He, Y.\& Liu, H. (2005). The Peer Group as a Context: Moderating Effects on Relations between Maternal Parenting and Social and School Adjustment in Chinese Children. Child Development, 76(2), 417 - 434.

Cicchetti, D., \& Schneider-Rosen, K. (1986). An Organizational Approach to Childhood Depression. in M. Rutter, C. E. Izard, \& P. E. Read (Eds.), Depression in Young People (pp. 71-134). New York: Guilford Press.

Cole, P. M.; Martin, S. E., \& Dennis, T. A. (2004). Emotion Regulation as a Scientific Construct: Methodological Challenges and Directions for Child Development Research. Child Development, 75, 317-333.

Coplan, R. J.; Reichel, M. \& Rowan, K. (2009). Exploring the Associations between Maternal Personality, Child Temperament, and Parenting: A Focus On Emotions. Personality and Individual Differences 46, 241-246.

Denham, S. (2007). Dealing with Feelings: How Children Negotiate The Worlds of Emotions and Social Relationships. Cognitie, Creier, Comportament / Cognition, Brain, Behavior, $11(1)), 1-48$.

Denham, S. A.; Workman, E.; Cole, P. M.; Weissbrod, C.; Kendziora, K. T., \& Zahn- Waxler, C. (2000). Prediction Of Externalizing Behavior Problems from Early to Middle 
Childhood: The Role of Parental Socialization and Emotion Expression. Development and Psychopathology, 12, 23-45.

Eisenberg, N., \& Morris, A. S. (2002). Children's emotion-related regulation. In H. Reese, \& R. Kail (Eds.), Advances In Child Development And Behavior (Vol. 30, pp. 189-229). San Diego, CA: Academic Press.

Eisenberg, N.; Cumberland, A., \& Spinrad, T. L. (1998). Parental Socialization of Emotion. Psychological Inquiry, 9, 241 - 273.

Eisenberg, N.; Valiente, C.; Morris, A. S.; Fabes, R. A.; Cumberland, A.; Reiser, M., et al. (2003). Longitudinal Relations Among Parental Emotional Expressivity, Children's Regulation, And Quality of Socioemotional Functioning. Developmental Psychology, $39,2-19$.

Eisenberg, N.; Zhou, Q.; Spinrad, T.L.; Valiente, C.; Fabes, R. A. \& Liew, J. (2005). Relations among Positive Parenting, Children's Effortful Control, and Externalizing Problems: A Three-Wave Longitudinal Study. Child Development, 76,(5), 1055 1071.

Elias, M., J.; Zins, J. E.; Weissberg, R. P.; Frey, K. S; Greenberg, M. T.; Haynes, N. M., Kessler, R.; Schwab-Stone, M, E. \& Shriver, T. P. (1997). Promoting Social and Emotional Learning, Association for Supervision and Curriculum Development. U.S.A.

Ergin, F. E. (2000). A Study on the Relationship Between Emotional Intelligence Levels and Sixteen Personality Characteristics of The University Students. (master thesis). Turkey; Selçuk University.

Fabes, R.; Eisenberg, N.; Hanish, L. \& Spinrad, T. (2001). Preschoolers' Spontaneous Emotion Vocabulary: Links to Likability. Early Education and Development, 12, 11-27.

Goldsmith, H. H., \& Davidson, R. J. (2004). Disambiguating the Components of Emotion Regulation. Child Development, 75, 361-365.

Goleman, D. (2001). Emotional Intelligence. (Translator: Banu Seçkin Yüksel), İstanbul: Varlık Publication.

Goodvin, R.; Carlo, G.; Torquati, J. (2006). The Role of Child Emotional Responsiveness and Maternal Negative Emotion Expression in Children's Coping Strategy Use. Social Development, 15(4), 591-611.

Gottman, J. M.; Katz, L. F. \& Hooven, C. (1997). Metaemotion: How Families Communicate Emotionally. Mahwah, NJ: Erlbaum.

Hughes, C.; Dunn, J., \& White, A. (1998). Trick or Treat? Uneven Understanding of Mind And Emotion And Executive Dysfunction In Hard-To-Manage Preschoolers. Journal of Child Psychology and Psychiatry, 39, 981-994.

Jewell, J. D.; Krohn, E. J.; Scott, V. G.; Carlton, M. \& Meinz, E. (2008). The Differential Impact of Mothers' And Fathers' Discipline on Preschool Children's Home And Classroom Behavior. North American Journal of Psychology, 10 (1), 173-188.

Kerns, K.; Klepac, L., \& Cole, A. K. (1996). Peer Relationships and Preadolescents' Perceptions of Security in The Child-Mother Relationship. Developmental Psychology, 32, 457-466.

Laible, D. J., \& Thompson, R. A. (1998). Attachment and Emotional Understanding in Preschool Children. Developmental Psychology, 34, 1038 - 1045.

LeCompte G.; LeCompte A.\& Özer, S. et. al. (1978). Child-rearing Attitudes of Mothers in Three Socio-Economic Level, the Adaptation of Parental Attitudes Research Inventory. Journal of Turkish Psychology, 1:5-8. 
Lopez, N.L.\& Bonenberger, J.L., \& Schneider, H.G. (2001). Parental Disciplinary History Current Levels of Empathy, and Moral Reasoning In Young Adults. North American Journal of Psychology, 3(1), 193-204.

Marr, K. \& Ezeife, A . (2008). Empathy, Authoritarianism, and Recalled Parental Attitudes in Child and Youth Workers. Relational Child and Youth Care Practice, 21(1), 26-

Maughan, A. \& Cicchetti, D. (2002). Impact of Child Maltreatment and Interadult Violence on Children's Emotion Regulation Abilities And Socioemotional Adjustment. Child Development, 73(5), 1525;1542.

Mayer, J. D. \& Caruso, D. R. and Salovey, P. (2002) 'Selecting a Measure of Emotional Intelligence', in R. Bar-On and J. D. Parker (eds) The Handbook of Emotional Intelligence, pp. 320-42. San Francisco, CA: Jossey-Bass.

Mayer, J. D. \& Salovey. M. (1997). What İs Emotional İntelligence?. Emotional Development And Emotional Intelligence. Edited By: Peter Salovey And David J. Sluyter, U.S.A.

McLaughlin, A. E.; Campbell, F. A.; Pungello, E. P. \& Skinner, M. (2007). Depressive Symptoms In Young Adults: The Influences of The Early Home Environment and Early Educational Child Care. Child Development, 78, (3), 746 - 756.

Melmed, M. E. (1998). Talking with parents about emotional development. Pediatrics, 102 (5); 1317-1326.

Morris, A. S.; Silk, J. S.; Steinberg, L.; Myers, S. S.\& Robinson, L. R. (2007). The Role of the Family Context in the Development of Emotion Regulation. Social Development, 16, 2, 361-368.

Nixon, C., \& Watson, A. (2001). Family Experiences and Early Emotion Understanding. Merrill-Palmer Quarterly, 47, 300-322.

Ontai, L. L., \& Thompson, R. A. (2002). Patterns of Attachment and Maternal Discourse Effects On Children's Emotion Understanding From 3 To 5 Years of Age. Social Development, 11, 433-450.

Ozabac1, N. (2006). "Emotional Intelligence and Family Environment". Kyrgyzstan-Turkey Manas University The Journal of Social Sciences 16 (6), 169-177.

Parke, R. D. (1994). Progress, Paradigms, and Unresolved Problems: A Commentary On Recent Advances In Our Understanding of Children's Emotions. Merrill-Palmer Quarterly, 40, 157-169.

Parke, R. D.; Cassidy, J.; Burks, V. M.; Carson, J. L.\& Boyum, L. (1992). Familial Contribution to Peer Competence Among Young Children: the Role of Interactive and Affective Processes. in R. D. P. G. W. Ladd (Ed.), Family-peer relationships Modes of linkage (pp. 107-134). Hillsdale, NJ: Erlbaum.

Petrides, K. V.; Pita, R. \& Kokkinaki, F.(2007). The Location of Trait Emotional Intelligence in Personality Factor Space. British Journal of Psychology, 98, 273-289

Raikes, H. A., \& Thompson, R. A. (2006). Family Emotional Climate, Attachment Security and Young Children's Emotion Knowledge In A High Risk Sample. British Journal of Developmental Psychology, 24(1), 89-104.

Ramsden, S. R., \& Hubbard, J. A. (2002). Family Expressiveness and Parental Emotion Coach-Ing: Their Role in Children's Emotion Regulation and Aggression. Journal of Abnormal Child Psychology, 30, 657-667.

Rubin, K. H., \& Burgess, K. (2002). Parents Of Aggressive and Withdrawn Children (2nd ed.. In M. Bornstein Ed.). Handbook of Parenting (Vol. 1, pp. 383-418). Hillsdale, NJ: Sage. 
Scheroeder, V. M. \& Kelley M. L. (2009). Associations between Family Environment, Parenting Practices, and Executive Functioning Of Children with and without Adhd. Journal of Child \& Family Studies, 18:227-235.

Schmitz, M. F. (2006) Influence of Social and Family Contexts on Self-Esteem of Latino Youth. Hispanic Journal of Behavioral Sciences, 28, 516-530.

Shapiro, L. E. (2000). How To Rise A Child with High Emotional Intelligenc. (translator: Ümran Kartal), İstanbul: Varlık publications.

Suess, G.J.; Grossmann, K.E. \& Sroufe, L.A. (1992). Effects of Infant Attachment to Mother on Quality of Adaptation in Preschool. From Dyadic To Individual Organization of Self. International Journal of Behavioral Development, 15, 43-65.

Sullivan, A. K. (1999). The Emotional Intelligence Scale For Children. U.S.A.: The Faculty Of The Curry School Of Education., Univesity Of Virginia. (PhD Thesis).

Sung, H. Y. (2011). The Influence of Culture on Parenting Practices of East Asian Families and Emotional Intelligence of Older Adolescents a Qualitative Study. School Psychology International, 31(2): 199-214.

Thompson, R. A. (1994). Emotion Regulation: A Theme In Search Of Definition. In N. A. Fox $(E d$.$) , The Development of Emotion Regulation: Biological and Behavioural$ Considerations. Monographs of the Society for Research in Child Development, Serial No. 240, 259 (242-243), 225-252.

Thompson, R. A. (1998). Early Socio-Personality Development. In W. Damon (Series Ed.) \& N. Eisenberg (Vol. Ed.), Handbook of child psychology: Social and personality development (Vol. 3, pp. 25-104). New York: Wiley.

Walden, T. A., \& Smith, M. C. (1997). Emotion Regulation. Motivation and Emotion, 21, 7-25.

Ulutas, I. \& Omeroglu, (2007). The Effects of An Emotional Intelligence Education Program on the Emotional Intelligence of Children. Social Behavior And Personality, 35 (10), 1365-1372, ISSN: 0301-2212

Warhol, J. G. (1998). Facilitating and Encouraging Healthy Emotional Development. Pediatrics, 102(5), 1330-1331.

Webster-Stratton, C. \& Herman, K. C. (2010). Disseminating Incredible Years Series EarlyIntervention Programs: Integrating and Sustaining Services between School And Home. Psychology in the Schools, 47, 36-54. 


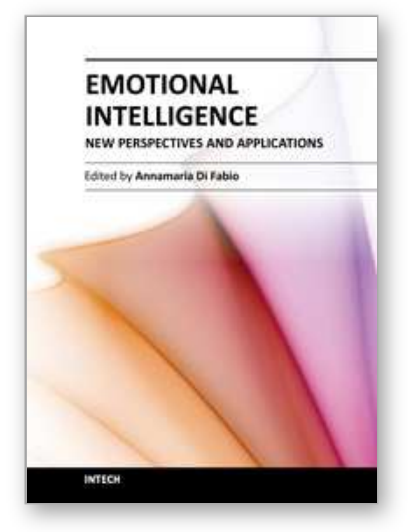

\author{
Emotional Intelligence - New Perspectives and Applications \\ Edited by Prof. Annamaria Di Fabio
}

ISBN 978-953-307-838-0

Hard cover, 288 pages

Publisher InTech

Published online 01, February, 2012

Published in print edition February, 2012

Emotional intelligence is an emerging construct for applied research and possible interventions, both in scholastic, academic and educational contexts, organizational contexts, as well as at an individual level in terms of people's well-being and life satisfaction. From the presented contributions, it emerges how this volume is characterized by an interest to give an international overview rich of stimuli and perspectives for research and intervention, in relation to a promising variable of current interest, such as emotional intelligence. The goal is that this book further contributes to the affirmation of a particularly promising variable, such as emotional intelligence, which requires a greater interest and attention in both research and application field.

\title{
How to reference
}

In order to correctly reference this scholarly work, feel free to copy and paste the following:

Ilkay Ulutas and Esra Omeroglu (2012). Maternal Attitudes, Emotional Intelligence and Home Environment and Their Relations with Emotional Intelligence of Sixth Years Old Children, Emotional Intelligence - New Perspectives and Applications, Prof. Annamaria Di Fabio (Ed.), ISBN: 978-953-307-838-0, InTech, Available from: http://www.intechopen.com/books/emotional-intelligence-new-perspectives-and-applications/maternalattitudes-emotional-intelligence-and-home-environment-and-their-relations-with-emotional-in

\section{INTECH}

open science | open minds

\author{
InTech Europe \\ University Campus STeP Ri \\ Slavka Krautzeka 83/A \\ 51000 Rijeka, Croatia \\ Phone: +385 (51) 770447 \\ Fax: +385 (51) 686166 \\ www.intechopen.com
}

\author{
InTech China \\ Unit 405, Office Block, Hotel Equatorial Shanghai \\ No.65, Yan An Road (West), Shanghai, 200040, China \\ 中国上海市延安西路65号上海国际贵都大饭店办公楼405单元 \\ Phone: $+86-21-62489820$ \\ Fax: $+86-21-62489821$
}


(C) 2012 The Author(s). Licensee IntechOpen. This is an open access article distributed under the terms of the Creative Commons Attribution 3.0 License, which permits unrestricted use, distribution, and reproduction in any medium, provided the original work is properly cited. 